\title{
A METHOD FOR THE DETERMINATION OF FORMIMINOGLUTAMIC ACID IN URINE ${ }^{1}$
}

\author{
By HERBERT TABOR AND LILLIAN WYNGARDEN \\ (From the National Institute of Arthritis and Metabolic Diseases, National Institutes of Health, \\ Bethesda, Md.)
}

(Submitted for publication December 9, 1957; accepted February 6, 1958)

Formimino-L-glutamic acid, an intermediate in the metabolism of histidine $(1,2)$, accumulates in the urine of folic acid-deficient rats (3-7). The urinary formiminoglutamic acid has also been reported to be increased in macrocytic anemia of pregnancy and in patients treated with folic acid antagonists (8-10). These findings can be attributed to a lack of tetrahydrofolic acid (THF), since enzymatic studies have shown (11-14) that THF is required for the further metabolism of formiminoglutamic acid.

The accumulation of formiminoglutamic acid in the urine can be used as a test for folic acid deficiency both in rats and in patients. The available assay for formiminoglutamic acid, based on the microbiological assay of the glutamic acid formed from formiminoglutamic acid by heating $(4,9)$, is relatively inconvenient and inaccurate. The assay is complicated by the fact that glutamic acid and glutamine are normally present in urine, as well as by the variable conversion of these compounds to pyrrolidone carboxylic acid during the heating step.

In this paper a sensitive spectrophotometric method is presented for the assay of formimino-Lglutamic acid in the urine. This method is based on enzymatic reactions (1) and (2) [Diagram 1] which we have recently (14) demonstrated to be involved in the metabolism of formiminoglutamic acid.

The amount of 5,10-methenyl-THF formed in reaction (2) is easily measured spectrophotometrically, since this compound has a high absorption in the ultraviolet with an extinction coefficient of 25,000 at $350 \mathrm{~m} \mu(15-18)$. During the course of the reaction, however, 5,10-methenyl-

\footnotetext{
1 Preliminary reports on this method have been presented at the meetings of the American Society of Biological Chemistry, April, 1957, and the American Society for Pharmacology and Experimental Therapeutics, September, 1957.
}

THF is converted nonenzymatically to 10 -formylTHF in accordance with reaction (3). ${ }^{2}$ The latter compound, however, is completely reconverted to 5,10-methenyl-THF upon acidification.

In the quantitative procedures presented here, ${ }^{3}$ urine is incubated in phosphate buffer with a mixture of the transferase, cyclodeaminase and tetrahydrofolic acid. The mixture is then acidified, and the concentration of 5,10-methenyl-THF is calculated from the optical density at $350 \mathrm{~m} \mu$.

\section{EXPERIMENTAL}

Enzyme preparation. Commercial frozen hog liver is used as the starting material; this can be stored at $-20^{\circ}$ C. for as long as six months without loss of activity.

Step A. For the preparation of "acetone powders," 100 gram portions of hog liver are homogenized in a Waring blendor with approximately $500 \mathrm{ml}$. of acetone (technical grade) at room temperature for one minute; the mixture is then filtered rapidly through a large Büchner funnel. The moist filter cake is homogenized again with acetone, refiltered, passed through a coarse screen, and dried at room temperature overnight. The resultant powder can be stored over a drying agent in vacuo at $-20^{\circ} \mathrm{C}$. for as long as six months.

Step $B$. Extracts are prepared by gently stirring 160 grams of acetone powder with $1,600 \mathrm{ml}$. of water at room temperature. After 15 minutes the suspension is centrifuged in an angle centrifuge at $20,000 \times \mathrm{G} *$ for $15 \mathrm{~min}$ -

2 The nonenzymatic conversion of 5,10-methenyl-THF to 10 -formyl-THF at $\mathrm{pH} 7$ is catalyzed by the phosphate buffer. This reaction is also rapidly catalyzed by the enzyme cyclohydrolase $(14,16,17)$. This activity is not present, however, in the partially purified preparations described in this paper.

3 Silverman, Gardiner, and Condit (19) have recently developed a method for formiminoglutamic acid estimation which depends on the formation of 10-formyl-THF from formiminoglutamic acid and folic acid in a crude chicken liver homogenate. The latter contains the enzymes mentioned above plus a folic acid reductase. In this precedure the 10 -formyl-THF is converted to 5-formyl-THF by heating, and the latter is assayed microbiologically.

4 Lower centrifugal speeds are satisfactory at this point. 
(1)
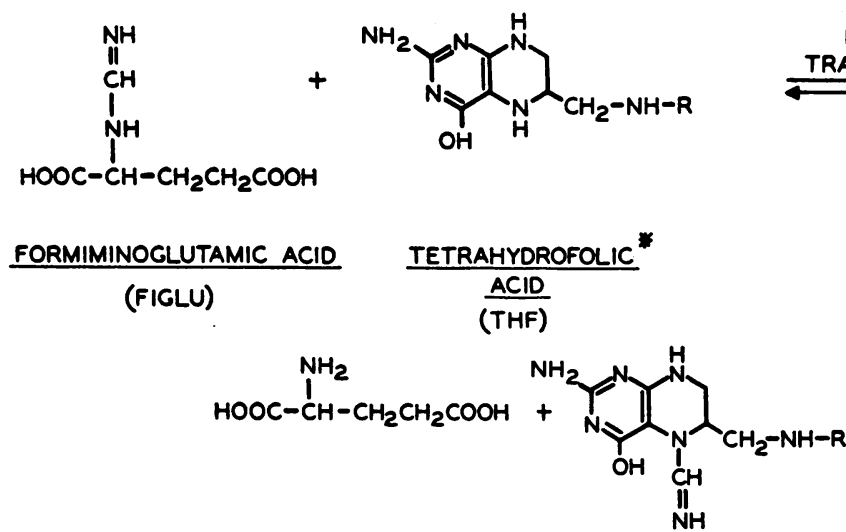

GLUTAMIC ACID 5-FORMIMINO-THF

(2)<smiles>[R]NCC1CNc2nc(N)nc(O)c2N1CN</smiles>
5- FORMIMINO-THF<smiles></smiles>

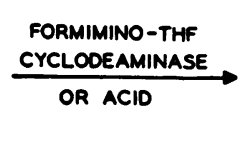<smiles>CN(CN1CCNc2nc(N)nc(O)c21)[N+](=O)[O-]</smiles>

(3)

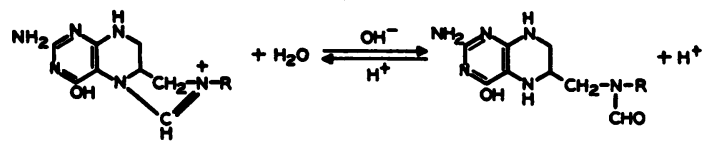
3, 10-METHENYL-THF

\section{Diagram 1}

utes, and the supernatant solution collected. ${ }^{5}$ Subsequent steps are carried out at 1 to $3^{\circ} \mathrm{C}$.

5 The enzyme purification procedure presented here has been very reproducible, and enzymatic assays have not ordinarily been carried out after each step. If desired, however, the following rapid assay can be used to follow the purification procedure. Although more precise assays for each enzyme activity are available (to be published), they are not necessary for the purposes of this paper.

The assay mixture is similar to that described below under "assay," and contains $0.1 \mathrm{ml}$. of $1 \mathrm{M}$ potassium phosphate buffer ( $\mathrm{pH} 7.2), 0.1 \mathrm{ml}$. of the tetrahydrofolic acid-mercaptoethanol solution, 5 micromoles of sodium formiminoglutamate, enzyme solution, and water to $1 \mathrm{ml}$. After five minutes at $25^{\circ} \mathrm{C}$., $0.3 \mathrm{ml}$. of 10 per cent perchloric acid is added. The mixture is heated for onehalf to one minute in a boiling water bath, cooled im-
Step $C$. Three hundred grams of anımonium sulfate is dissolved in $1,400 \mathrm{ml}$. of this supernatant solution. After approximately one hour the precipitate is collected by centrifugation at $20,000 \times \mathrm{G}$ for 15 minutes. 4 The precipitate is thoroughly suspended in 30 to $50 \mathrm{ml}$. of $\mathrm{H}_{2} \mathrm{O}$ and stored overnight. The suspension is then centrifuged for two hours at $30,000 \times G$ in an angle centrifuge, and the supernatant solution is discarded. The precipitate is then dissolved in $38 \mathrm{ml}$. of $0.2 \mathrm{M}$ sodium acetate; after four hours the solution is centrifuged, and any insoluble material is discarded. This enzyme fraction is used for the assay procedure.

This preparation contains both the transferase and the cyclodeaminase. It has been stored with little loss of activity at $-20^{\circ} \mathrm{C}$. for over six months, at $0^{\circ} \mathrm{C}$. for over

mediately in ice water, centrifuged, and the optical density of the supernatant solutions measured at $365 \mathrm{~m} \mu$ against a suitable blank without formiminoglutamic acid. Under these conditions $0.01 \mathrm{ml}$. of this extract results in an increase in optical density of 0.6 to $\mathbf{1 . 0}$.

The same assay procedure can be used to follow Step $C$, using suitable dilutions of the enzyme. Step C results in a purification of approximately one hundredfold with about a 50 per cent yield of both the transferase and the cyclodeaminase. 


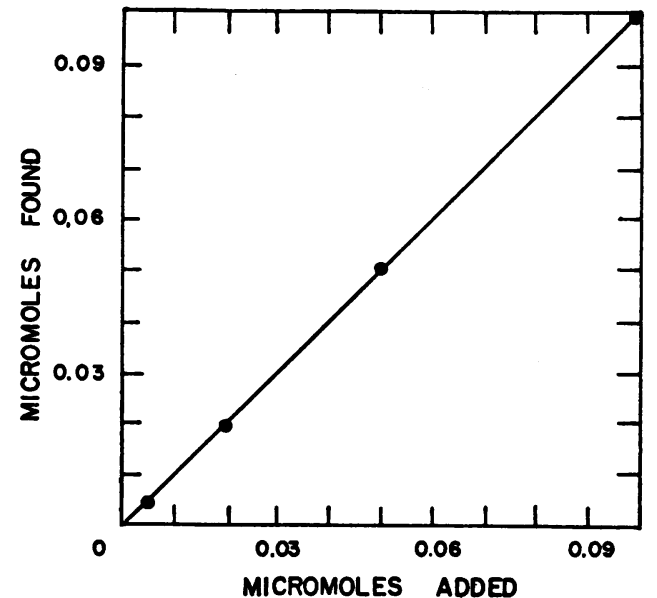

Fig. 1. Recovery of Formiminoglutamic Acid Added TO URINE

Varying quantities of formiminoglutamic acid were added to $0.45 \mathrm{ml}$. aliquots of human urine. The mixture was then assayed for the formiminoglutamic acid content.

three months, and as a lyophilized powder at $-20^{\circ} \mathrm{C}$. for over three months. Details on the further purification and separation of these enzymes will be published separately.

Tetrahydrofolic acid. Folic acid is reduced by the method of Jaenicke and Greenberg, as modified by Rabinowitz and Pricer (18). Solutions are prepared by dissolving $88 \mathrm{mg}$. of tetrahydrofolic acid in $18 \mathrm{ml}$. of $1.1 \mathrm{M}$ mercaptoethanol plus $2 \mathrm{ml}$. of $0.2 \mathrm{~N} \mathrm{KOH}$. These solutions are usually 70 to 80 per cent pure, and contain 7 to 8 micromoles of $d l$-THF per $\mathrm{ml}$. They are stored in test tubes in vacuo in the dark at $0^{\circ} \mathrm{C}$., and have been stable for at least three months. Aliquots are transferred to small test tubes for daily use. The synthetic procedures used for the preparation of formiminoglutamic acid, formiminoaspartic acid, and formylglutamic acid have been described previously $(2,20)$.

Assay procedure. Urine (containing less than $0.1 \mathrm{mi}-$ cromole of formiminoglutamic acid), $0.25 \mathrm{ml}$. of the enzyme preparation, $0.1 \mathrm{ml}$. of tetrahydrofolic acid solution,

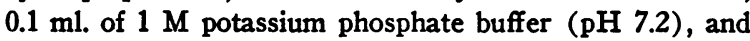
water up to $1 \mathrm{ml}$. are incubated in narrow $3 \mathrm{ml}$. test tubes at $25^{\circ} \mathrm{C}$. for 30 minutes. A "control" mixture is prepared in the same way except for the omission of enzyme. At the end of the incubation period $0.3 \mathrm{ml}$. of 10 per cent perchloric acid ${ }^{6}$ is added; after two to two and one-fourth hours the solutions are centrifuged, 7 and the optical density at 350 or $365 \mathrm{~m} \mu$ is read against the

6 The perchloric acid is added both to deproteinize the incubation mixture and to convert formiminotetrahydrofolic acid and 10-formyltetrahydrofolic acid to 5,10methenyl-THF.

7 Alternatively, the mixture, after the addition of perchloric acid, is heated for one-half to one minute in a boiling water bath, cooled immediately in ice water, centrifuged, and the optical density of the supernatant solutions measured. "control" cuvette. If the optical density is too high, the readings can be taken at $380 \mathrm{~m} \mu$ where the extinction coefficient is lower. The optical density readings were corrected for a small enzyme blank (0.03 to 0.09$)$. This value was obtained by incubating buffer, enzyme and THF; after the addition of perchloric acid (as above), the optical density was read against a similar mixture without enzyme.

The spectrophotometric readings are made in semimicrocuvettes (1.0 to $1.5 \mathrm{ml}$. volume) with a $1 \mathrm{~cm}$. light path. The optical density obtained with 0.01 micromole of formiminoglutamic acid in $1.3 \mathrm{ml}$. volume under these conditions is 0.19 at $350 \mathrm{~m} \mu, 0.17$ at $365 \mathrm{~m} \mu$, or 0.11 at $380 \mathrm{~m} \mu$. Therefore, the quantity of formiminoglutamic acid in micromoles in the aliquot used is calculated by multiplying the corrected optical density by 0.052 at 350 $\mathrm{m} \mu, 0.059$ at $365 \mathrm{~m} \mu$, or 0.088 at $380 \mathrm{~m} \mu$. The sensitivity of the procedure is approximately 0.001 micromole.

Recovery of formiminoglutamic acid from urine. Good recovery is obtained when varying quantities of formiminoglutamic acid are added to water or to urine (Figure 1). Duplicate assays usually agree within 0.001 micromole, even when the determinations are carried out with different enzyme and tetrahydrofolic acid preparations. No inhibitory effects are observed with rat urine or with human urine, even after amethopterin (methotrexate) treatment (21).

Specificity. With the assay conditions used, no reaction $(<0.002$ micromole) is obtained with 10 micromoles of L-methionine, L-serine, sodium formate, L-histidine, ammonium chloride, L-glutamic acid, formamide, formiminoglycine or glycine.

The enzyme preparation reacts very slowly with both formylglutamic acid $(13,22)$ and with formiminoaspartic acid. With 1 to 10 micromoles of either formylglutamic acid or formiminoaspartic acid, a reading equivalent to approximately 0.06 micromole of formiminoglutamic acid is obtained. There is no evidence at present that urine contains either formiminoaspartic acid or formylglutamic acid.

The enzyme preparation still has traces of urocanase. 8 However, even with 10 micromoles of urocanic acid, a maximum of 0.013 micromole of formiminoglutamic acid is formed. Thus, no significant error is introduced in the urinary assays at the levels of urocanic acid usually found in urine. Any error due to urocanic acid can be detected by the alkaline hydrolysis procedure described below, since urocanic acid is relatively stable under these condi-

8 The enzyme preparation contains approximately 0.3 per cent of the urocanase activity found in the crude extract. A preparation entirely free of urocanase can be obtained by treating $20 \mathrm{ml}$. of the enzyme solution with $2.0 \mathrm{ml}$. of a $3 \mathrm{M}$ sodium acetate buffer $[\mathrm{NaAC} / \mathrm{HAc}=$ $90 / 10]$ at $0^{\circ} \mathrm{C}$. After four hours the precipitate is collected by centrifugation at $30,000 \times \mathrm{G}$ for 30 minutes, and dissolved in $20 \mathrm{ml}$. of $0.1 \mathrm{M}$ triethanolamine sulfate buffer ( $\mathrm{pH} 7.1$ ). This preparation represents a one thousandfold purification of both the transferase and the cyclodeaminase. 
tions ( $>95$ per cent remaining after autoclaving for two hours).

Although no additional procedures have been used routinely for the further identification of the formiminoglutamic acid in urine, several procedures are available for this purpose:

1. Alkaline hydrolysis. Formiminoglutamic acid is very unstable at an alkaline $\mathrm{pH}$. It has a half-life at $25^{\circ} \mathrm{C}$. of 10 minutes in $1 \mathrm{~N} \mathrm{KOH}, 20$ minutes at $\mathrm{pH} 11.5$, 70 minutes at $\mathrm{pH} 10.8$, and 40 hours at $\mathrm{pH}$ 9.2. To destroy the formiminoglutamic acid, therefore, the urine is adjusted to $\mathrm{pH} 11.5$ with $\mathrm{KOH}$ and incubated at $25^{\circ} \mathrm{C}$. for four hours. This alkali treatment causes a decrease in the assay of over 97 per cent; the small residual reading is due to formylglutamic acid which accumulates during the mild alkaline hydrolysis, and, as indicated above, reacts slowly in the enzyme assay. To obtain complete hydrolysis, the following conditions are used. Two ml. of urine is neutralized with $\mathrm{KOH} ; 0.1 \mathrm{ml}$. of $6 \mathrm{~N} \mathrm{KOH}$ is then added, and the mixture is autoclaved for two hours at 15 pounds pressure. We have observed complete hydrolysis under these conditions in all the urine samples that we have tested.

Formiminoglutamic acid is very stable in acid at $25^{\circ} \mathrm{C}$., showing no destruction after several months in $0.1 \mathrm{~N}$ acetic acid, $0.1 \mathrm{~N} \mathrm{HCl}$, and $6 \mathrm{~N} \mathrm{HCl}$. At $\mathrm{pH} 7$ it is relatively stable at $0^{\circ} \mathrm{C}$., but is destroyed ( $>98$ per cent) by autoclaving for two hours (4).

2. Alkaline ferricyanide-nitroprusside reaction. Formiminoglutamic acid in urine may also be determined colorimetrically by a modification of the method used by Rabinowitz and Pricer for formiminoglycine determination $(23,24)$. Urine plus $\mathrm{H}_{2} \mathrm{O}(0.5 \mathrm{ml}$. volume $)$ is mixed with $2 \mathrm{ml}$. of saturated sodium borate and $0.5 \mathrm{ml}$. of the ferricyanide-nitroprusside reagent ( 4 grams each of $\mathrm{NaOH}$, potassium ferricyanide, and sodium nitroprusside in $120 \mathrm{ml}$. of $\mathrm{H}_{2} \mathrm{O}$ ). The optical density at $485 \mathrm{~m} \mu$ is read after 30 minutes at room temperature against a corresponding blank. The latter is prepared by preincubating $0.3 \mathrm{ml}$. urine with $0.1 \mathrm{ml}$. of $2.5 \mathrm{~N} \mathrm{KOH}$ for 2 hours at $25^{\circ} \mathrm{C}$. to destroy the formiminoglutamic acid present; the mixture is then neutralized with $0.1 \mathrm{ml} .2 .5 \mathrm{~N} \mathrm{HCl}$, and assayed by the above procedure.

Under these conditions an optical density of 0.60 is obtained with 1 micromole of formiminoglutamic acid. Thus, this method is considerably less sensitive than the enzymatic procedure. The colorimetric assay has been satisfactory, however, for following the excretion of formiminoglutamic acid in the urines of folic acid-deficient rats, in which large amounts of this material are excreted.

3. Chromatography. Aliquots of urine containing large quantities of formiminoglutamic acid can be chromatographed on Whatman No. 1 paper in $t$-butanol 70, formic acid $15, \mathrm{H}_{2} \mathrm{O} 15\left(\mathrm{R}_{\mathrm{t}}=0.52\right)(2,20,25)$ or in the phenolphosphate-citrate solvent of Broquist (9). After removal of the solvent, the paper is placed in an atmosphere of ammonia for two hours to hydrolyze the formiminoglutamic acid (20). The ammonia vapors are removed by aeration; the paper is sprayed with a ninhydrin solution, and the color is developed at room temperature. A control paper is usually run without the ammonia treatment, since formiminoglutamic acid gives only a very weak spot with ninhydrin under these conditions.

Formiminoglutamic acid may also be chromatographed on Dowex 50 and Dowex 1, as previously described (2, $4,20)$.

\section{DISCUSSION}

Formiminoglutamic acid has been shown to accumulate in the urine in folic acid deficiency (310). A quantitative determination of urinary formiminoglutamic acid is useful for following the excretion of this compound in folic acid-deficient animals (3-7), in patients treated with anti-folic acid compounds $(9,10)$, and in certain macrocytic anemias (8).

The method presented here affords a simple, specific spectrophotometric procedure for the determination of formiminoglutamic acid, which is applicable to studies on its excretion in urine. We have recently used this method for following the excretion of formiminoglutamic acid in the urine during the development of a folic acid deficiency in rats; this was induced by feeding a folic aciddeficient diet, containing succinylsulfathiazole. These data, which will be reported in greater detail elsewhere (7), are summarized in Table I.

In the accompanying paper (21) the use of this procedure to assay the formiminoglutamic acid concentration in various human urines has been described.

\section{SUM MARY}

A sensitive spectrophotometric method is presented for the assay of formiminoglutamic acid in the urine.

TABLE I

Effect of folic acid deficiency on formiminoglutamic acid excretion

\begin{tabular}{ccc}
\hline \hline Day of diet* & $\begin{array}{c}\text { Folic acid } \\
\text { administered }\end{array}$ & $\begin{array}{c}\text { Formimino- } \\
\text { glutamic } \\
\text { acid excreted }\end{array}$ \\
\hline 7 & $0.05 \mu M /$ rat/day & $\mu M / 7$ hr. period \\
14 & 0 & 0.22 \\
21 & 0 & 1.29 \\
28 & 0 & 2.06 \\
35 & 0 & 9.66 \\
41 & 0 & 21.2 \\
43 & 0 & 36.5 \\
45 & + & 0.38 \\
& + & 0.18 \\
\hline
\end{tabular}

* A folic acid-deficient diet, containing 1 per cent succinylsulfathiazole, was fed to six weanling rats. Further details on this experiment will be published subsequently in a more detailed study of the urinary changes in folic acid deficiency (7). 


\section{REFERENCES}

1. Borek, B. A., and Waelsch, H. The enzymatic degradation of histidine. J. biol. Chem. 1953, 205, 459.

2. Tabor, H., and Mehler, A. H. Isolation of $N$-formylL-glutamic acid as an intermediate in the enzymatic degradation of L-histidine. J. biol. Chem. 1954, 210, 559.

3. Bakerman, H. A., Silverman, M., and Daft, F. S. Influence of succinylsulfathiazole and folic acid on glutamic acid excretion. J. biol. Chem. 1951, 188, 117.

4. Silverman, M., Gardiner, R. C., and Bakerman, H. A. The nature of the glutamic acid excreted in folic acid deficiency. J. biol. Chem. 1952, 194, 815.

5. Tabor, H., Silverman, M., Mehler, A. H., Daft, F. S., and Bauer, H. L-Histidine conversion to a urinary glutamic acid derivative in folic-deficient rats. $\mathrm{J}$. Amer. chem. Soc. 1953, 75, 756.

6. Seegmiller, J. E., Silverman, M., Tabor, H., and Mehler, A. Synthesis of a metabolic product of histidine. J. Amer. chem. Soc. 1954, 76, 6205.

7. Rabinowitz, J., and Tabor, H. The urinary excretion of formic acid and formiminoglutamic acid in folic acid-deficient rats. J. biol. Chem. In Press.

8. Daft, F. S. Certain Aspects of the Relations Between Nutrition and Liver Function. Symposium on Approaches to the Quantitative Description of Liver Function. San Francisco, U. S. Naval Radiological Defense Laboratory, 1958.

9. Broquist, H. P. Evidence for the excretion of formiminoglutamic acid following folic acid antagonist therapy in acute leukemia. J. Amer. chem. Soc. 1956, 78, 6205.

10. Luhby, A. L. Observations on the excretion of formiminoglutamic acid in folic acid deficiency in man. Clin. Res. Proc. 1957, 5, 8.

11. Slavik, K., and Matoulkova, V. Metabolism of folic acid. II. Conditions for the formylation of folic acid. Coll. Czech. chem. Comm. 1954, 19, 1032.

12. Miller, A., and Waelsch, $H$. The transfer of the formimino group of formamidinoglutaric acid to tetrahydrofolic acid. Arch. Biochem. 1956, 63, 263.

13. Miller, A., and Waelsch, $H$. Formimino transfer from formamidinoglutaric acid to tetrahydrofolic acid. J. biol. Chem. 1957, 228, 397.
14. Tabor, H., and Rabinowitz, J. C. Intermediate steps in the formylation of tetrahydrofolic acid by formiminoglutamic acid in rabbit liver. J. Amer. chem. Soc. 1956, 78, 5705.

15. May, M., Bardos, T. J., Barger, F. L., Lansford, M., Ravel, J. M., Sutherland, G. L., and Shive, W. Synthetic and degradative investigations of the structure of folinic acid-SF. J. Amer. chem. Soc. 1951, 73, 3067.

16. Rabinowitz, J. C., and Pricer, W. E., Jr. The enzymatic synthesis of $\mathrm{N}^{10}$-formyltetrahydrofolic acid and its role in ATP formation during formiminoglycine degradation. J. Amer. chem. Soc. 1956, 78, 4176.

17. Rabinowitz, J. C., and Pricer, W. E., Jr. Formiminotetrahydrofolic acid and methenyltetrahydrofolic acid as intermediates in the formation of $\mathrm{N}^{10}$ formyltetrahydrofolic acid. J. Amer. chem. Soc. 1956, 78, 5702.

18. Rabinowitz, J. C., and Pricer, W. E., Jr. An enzymatic method for the determination of formic acid. J. biol. Chem. 1957, 229, 321.

19. Silverman, M., Gardiner, R. C., and Condit, P. T. A method for the detection of $N$-formiminoglutamic acid in urine. J. nat. Cancer Inst. 1958, 20, 71.

20. Tabor, H., and Rabinowitz, J. Formiminoglycine, formimino-L-aspartic acid, formimino-L-glutamic acid in Biochemical Preparations. New York, John Wiley \& Sons, Inc., 1957, vol. 5, p. 100.

21. Hiatt, H., Goldstein, M., and Tabor, H. Urinary excretion of formiminoglutamic acid by human subjects after antifolic acid therapy. J. clin. Invest. 1958, 37, 829.

22. Silverman, M., Keresztesy, J. C., Koval, G. J., and Gardiner, R. C. Citrovorum factor and the synthesis of formylglutamic acid. J. biol. Chem. 1957, 226, 83.

23. Weber, C. J. The determination of guanidine bases in the blood. Proc. Soc. exp. Biol. (N. Y.) 1927, 24, 712 .

24. Rabinowitz, J. C., and Pricer, W. E., Jr. Purine fermentation by Clostridium cylindrosporum. J. biol. Chem. 1956, 222, 537.

25. Block, R. J. Estimation of amino acids and amines on paper chromatograms. Analyt. Chem. 1950, 22, 1327. 